\title{
Review
}

\section{Becoming political: Spinoza's vital republicanism and the democratic power of judgement}

\author{
Christopher Skeaff \\ University of Chicago Press, Chicago and London, 2018, xii+176 pp., \\ ISBN: 978-0-226-55547-8
}

Contemporary Political Theory (2020) 19, S116-S120. https://doi.org/10.1057/s41296019-00309-z; published online 24 January 2019

Christopher Skeaff's Becoming Political aspires simultaneously to offer a new interpretation of Spinoza's political philosophy, and to engage with contemporary political theory.

Substantively, the book articulates and defends an ideal of democratic politics whereby the state is open to its own reconstitution and internal transformation. Such an ideal stands opposed to the tendency in democratic theory and practice to try to fix the bounds of democracy: whether through a sovereigntist view of politics (whereby democracy just means implementing the sovereign decision of the democratic assembly) or a moral view of politics (whereby philosophers attempt to define and codify in advance the norms of appropriate democratic decisionmaking). On my reading, Skeaff envisions a sovereign state making laws, but he proposes that the sovereign's rule must exist in an agonistic relation with citizens debating, contesting, reformulating, and resisting those same laws. Citizen judgment challenges both specific laws, but also and more importantly it challenges meta-level considerations about what counts as fair game for political debate and who belongs in the political community. In other words, citizen judgment dynamically regulates the very boundaries of politics: hence, the book's title Becoming Political. This vision is 'agonistic' both insofar as it refuses to lay down any definitive principles or norms of political life, and also insofar as it refuses to resolve the ongoing contestation between the state and the populace in favour of one side or the other. It may be possible to some degree for a sovereign state to shut down such citizen judgment, but it is normatively undesirable for it to do so.

Skeaff's agonistic vision becomes clear incrementally across the book's five chapters. Successive chapters draw out this same agonistic structure within different contexts of Spinoza's political corpus. For instance, Chapter 1 interprets

(C) 2019 Springer Nature Limited. 1470-8914 Contemporary Political Theory Vol. 19, S2, S116-S120 
Spinoza's famous advocacy of a right to philosophise in terms of the interaction between the sovereign's 'jurisdiction' (its right to proclaim laws) and citizens' 'jurisprudence' (their popular contestation of laws). Chapter 2 interprets Spinoza's analysis of the dynamics of human affect in terms of the interplay between our mimetic desire for sameness (and the hope for harmony that it expresses) and the more ethical and rational desire for alliance across difference (even as it brings with it ineradicable conflict). A similar structure is at play in Chapter 3's contrast between rule by law and rule of law, Chapter 4's contrast between theology supporting sovereignty and theology transforming sovereignty, and Chapter 5's contrast between democracy as popular rule versus democracy as equal empowerment expressed through dissent to rule.

In putting forward such an ideal of politics, Skeaff builds on several diverse existing traditions of politics focused on non-domination: the Italian biopolitical tradition (Negri), the analytic republican tradition (Pettit), and the tradition taking judgment as politics' most distinctive term (Arendt). I take it that the book's primary contribution for contemporary political theory is a positive effort to synthesise and enrich the ideas of these other thinkers that Skeaff finds appealing. But what is the deficiency to be addressed? What precisely does Spinoza offer to this already dense theoretical landscape?

In Skeaff's hands, Spinoza's two key conceptual contributions are 'vital republicanism' and 'democratic judgment'. Neither of these are terms explicitly used by Spinoza. Rather, they are Skeaff's original efforts to organise and systematise the structure of Spinoza's political thought. The first, 'vital republicanism', points towards a conception of political life as having its own immanent norms; the second, 'democratic judgment', specifies the conditions under which those immanent norms find their fullest expression.

Let me venture to make explicit how these two concepts might address deficiencies in the traditions of non-domination mentioned above. One issue for an agonistic conception of politics is to explain why the openness of a state to contestation is necessarily good. What guarantee is there that the contestation is not a mere conflict of brute power, against which it would be better to put in place protections and limitations? Why is political 'agonism' desirable and not something that we should seek to overcome? Or in more cognitive terms, why should 'judgment' be prioritised over determinate norms; how does the appeal to judgment avoid being subjective or arbitrary? It is against such fundamental skepticism that Skeaff's deployment of Spinoza's political philosophy is fruitful. Skeaff appeals to Spinoza's idea of immanent normativity, whereby political life has a non-arbitrary normative grain, which nonetheless cannot be subsumed under a universal or fixed rule. Specifically, each human being has their own individual ingenium or complexion (the characteristic motions of their concrete embodied existence), for which certain things are useful (utile) and others thwarting. For Spinoza, virtue is nothing other than expressing and developing this individual nature, as we all strive

(c) 2019 Springer Nature Limited. 1470-8914 Contemporary Political Theory Vol. 19, S2, S116-S120 S117 
to do to the best of our ability, and do better in proportion as we improve our reason. But Spinozist reason is not monolithic: the diversity of ingenia means that there is no single dictate of reason given for everyone and for all time: in Skeaff's terms, each must exercise their own judgment. When the state does not seek to suppress this diversity, then it maximises its subjects' flourishing and in turn maximises its own flourishing. Democratic state sovereignty stands as necessary but insufficient to this maximisation. The state must establish laws to regulate interactions amongst diverse citizens. But at the same time, due to the very same embodied diversity, any such laws (or indeed any meta-rules for democratic politics) are only provisional. Thus we have 'vital republicanism': a political order governed by laws, but those laws themselves continually regenerated and reformulated by the immanent normativity of the political entity, articulated through the 'democratic judgment' of its citizens.

Becoming Political thus makes welcome contributions to both Spinoza studies and to contemporary political theory. My key reservation is that the book needs to do more to unpack the link between judgment and democracy.

First, granting (for the sake of argument) that the immanent normativity of a political order has a democratic structure, I was left unclear what accounts for Skeaff's confidence that this immanent normativity will tend to be expressed. Skeaff appears to take the view that appropriately egalitarian popular contestation to sovereignty will just emerge: formal democratic institutions and rights of free speech make the people individually sui juris, in control of their own right and able to exercise democratic judgment (for instance, see his discussion of the Black Lives Matter movement). Textually, this confidence relies heavily on the TheologicalPolitical Treatise's famous characterisation of democracy as a regime in which formal political equality allows everyone to take part in making the laws and thereby maintain their freedom (Spinoza, 2016a, 16.36). But even though the passage is famous, I think it is theoretically simplistic, and at odds with other elements of Spinoza's philosophy. Skeaff's own Chapter 2 grants that collective passional dynamics can go wrong. He also grants that the English revolution in Spinoza's own time failed to advance democracy. But in his discussion of contemporary democracy, he presumes that popular pressure will go right. Such a presumption seems to me to be contrary to Spinoza's own injunction to consider human behaviour 'like a thunderstorm' (Spinoza, 2016b, 1.4): one needs to focus on its bad and troublesome aspects, with a view to understanding their determinate causes. Specifically, what about when citizens fail to be exemplary citizens, and are animated by exclusionary rather than egalitarian passions? What about the fact that formally equal citizens are often not substantively sui juris, because they find themselves in relations of dependency (whether economic, occupational, informational, or something else) (Spinoza, 2016b, 2.8-11). In these cases, popular judgment may have no particular connection to democratic and egalitarian

S118 (c) 2019 Springer Nature Limited. 1470-8914 Contemporary Political Theory Vol. 19, S2, S116-S120 
outcomes. Skeaff's book could usefully be complemented by a more critical theory of popular judgment and its conditions of democratic success.

Second, and perhaps more troubling, I was left unconvinced that Spinoza's own understanding of political immanent normativity is so clearly democratic as Skeaff makes out. For Skeaff, the link between judgment and democracy seems to be grounded in the presumption that judgment is a unified whole: in particular, Skeaff does not seriously countenance the possibility of the philosophical or religious exercise of judgment and expression of ingenium being separated from the political exercise of judgment and equal political participation. But this is exactly the separation that Spinoza sanctions for commoners in an aristocracy. On the one hand, commoners should be allowed to pursue their own ends under fair terms, unmolested, and with religious and philosophical freedom. But on the other hand, they must be vigorously and systematically prevented from exerting political pressure on the patrician rulers (Spinoza, 2016b, 8.4-7). If this is done, aristocracy is presented as a regime which can be highly virtuous and sui juris, more so than many actually existing democracies. To be sure, good politics requires taking into account many and diverse points of judgment, but this can be ensured by maintaining a large and active decision-making council drawn from a wide patrician class. To be sure, the point of politics is not to transform humans into beasts or automata, but this is hardly the status of the commoners: they may be as philosophically and ethically developed as they like, they simply cannot participate in political decisions. To be sure, humans strive for what is useful to them and their community, but in the history of political thought the common good has often been conceived in an inegalitarian way, and it is not clear to me that Spinoza is so unequivocally modern as Skeaff presumes.

In sum, I do wonder whether Skeaff presents an excessively generous image of Spinoza as a theorist of democracy. But this does not count strongly against the book: after all, such an image is pervasive in contemporary Spinoza studies. Skeaff's achievement is to make the case for connecting Spinoza's politics with contemporary theorists of agonism and non-domination, and indeed to use Spinoza to bolster those theoretical tendencies.

\section{References}

Spinoza, B. (2016a). The Theological-Political Treatise. In The Collected Works of Spinoza, trans. Edwin Curley. Vol 2. Princeton: Princeton University Press, pp. 65-356.

(C) 2019 Springer Nature Limited. 1470-8914 Contemporary Political Theory Vol. 19, S2, S116-S120 S119 
Spinoza, B. (2016b). The Political Treatise. In The Collected Works of Spinoza, trans. Edwin Curley. Vol 2. Princeton: Princeton University Press, pp. 503-606.

Publisher's Note Springer Nature remains neutral with regard to jurisdictional claims in published maps and institutional affiliations.

Sandra Field Yale-NUS College, Singapore 138527, Singapore sandra.field@yale-nus.edu.sg 